\title{
Assurance of Learning and Assessment at the Business Degree Program and Major Levels
}

\author{
Faye X. Zhu \\ Rohrer College of Business, Rowan University, USA \\ Robert S. Fleming \\ Rohrer College of Business, Rowan University, USA
}

\begin{abstract}
This study presents one business school's experiences in simultaneously undergoing the accreditation processes of both the Association to Advance Collegiate Schools of Business International (AACSB) and the Middle States Commission on Higher Education (MSCHE). AACSB International is a worldwide accreditor of business schools, while MSCHE is a regional accreditor of colleges and universities in the Middle States region of the United States and several other locations internationally. It discusses the process of assurance of learning (AOL) and assessment at the degree program level for the business school's AACSB accreditation and at the major level for the institution's MSCHE accreditation.
\end{abstract}

Keywords: Assurance of learning, assessment, accreditation, AACSB, MSCHE

\section{INTRODUCTION}

The Association to Advance Collegiate Schools of Business International (AACSB) accreditation is a highly sought designation by business schools in the United States and around the world. It is recognized as the most prestigious accreditation a business program can earn. To date, 786 business schools in 53 countries and territories have earned AACSB accreditation (AACSB, 2017).

The Middle States Commission on Higher Education (MSCHE) is a non-governmental peerbased association, accrediting higher education institutions in the Middle States region of the United States and several other locations internationally. MSCHE accreditation is an important way that an institution can publically demonstrate its accountability and its commitment to striving for and achieving excellence in higher education. To date, MSCHE has accredited 525 institutions, with 19 of them from other countries (MSCHE, 2017b).

While AACSB accreditation is awarded to business programs, MSCHE accreditation is awarded to an institution of higher education. Thus a business school would receive AACSB accreditation, whereas its university would be accredited by a regional accrediting association such as MSCHE.

Both of these accreditations require demonstrated evidence of assurance of learning (AOL), i.e., demonstrating that a program's learning goals have been met. Yet their requirements are at the different levels. AACSB states that AOL activities should occur at a degree program level (e.g., bachelor's, master's), while MSCHE focuses on AOL activities at a major program level (e.g., Management, Marketing, etc.) 
This study presents one business school's experiences in simultaneously undergoing the accreditation processes of AACSB and MSCHE. It discusses the process of assurance of learning (AOL) and assessment at the degree program level for the business school's AACSB accreditation and at the major level for the institution's MSCHE accreditation. The lessons learned are discussed.

\section{Background}

AOL AT THE DEGREE PROGRAM LEVEL FOR AACSB ACCREDITATION

AACSB revised and adopted its business accreditation standards in 2013 (the 2013 Standards). These new standards represent major revisions from the prior 2003 accreditation standards (the 2003 Standards). These changes necessitated that business schools, pursuing initial accreditation or re-accreditation, fully understand the differences between the two sets of standards so as to work more effectively towards compliance with the new standards, including the related documentation requirements. A number of articles related to the 2013 Standards have appeared in the literature. These articles examined major changes in the 2013 Standards, as compared to the 2003 Standards (Abdelsamad, et al., 2015), surveyed AACSB member deans' perceptions towards the 2013 Standards (Miles, et al., 2015), and discussed the implications of the 2013 Standards for business faculty and deans (Miles, et al., 2014).

The 2013 AACSB accreditation standards consist of 4 sections and 15 standards, with the AOLrelated standards listed in Section 3 (see Table 1).

Table 1: The 2013 AACSB AOL-related Accreditation Standards

\begin{tabular}{|c|c|}
\hline Sections & Standards in Section 3 \\
\hline $\begin{array}{l}\text { 1. Strategic management and innovation (Standards 1- } \\
\text { 3) } \\
\text { 2. Participants-Students, faculty, \& professional staff } \\
\text { (Standards 4-7) } \\
\text { 3. Learning and teaching (Standards 8-12) } \\
\text { 4. Academic and professional engagement } \\
\text { (Standards 13-15) }\end{array}$ & $\begin{array}{l}\text { Standard 8: Curricula management \& AOL } \\
\text { Standard 9: Curriculum content } \\
\text { Standard 10: Student faculty interaction } \\
\text { Standard 11: Degree program educational } \\
\text { level, structure, \& equivalence } \\
\text { Standard 12: Teaching effectiveness }\end{array}$ \\
\hline
\end{tabular}

To align AOL activities with the 2013 accreditation standards, it is necessary to take a closer look at the 3 AOL-related standards in Section 3 (i.e., Standards 8, 9, and 11). Standard 8 states that "The school uses well-documented, systematic processes for determining and revising degree program learning goals; designing, delivering, and improving degree program curricula to achieve learning goals; and demonstrating that degree program learning goals have been met" (AACSB, 2013, p. 29). Standard 9 states that "Curriculum content is appropriate to general expectations for the degree program type and learning goals" (AACSB, 2013, p. 31). Standard 11 states that "Degree program structure and design, including the normal time-to-degree, are appropriate to the level of the degree program and ensure achievement of high-quality learning outcomes. Programs resulting in the same degree credential are structured and designed to ensure equivalence." (AASCB, 2013, p. 34)

It is important to understand that degree program learning goals stated in these AACSB accreditation standards refer to the educational expectations for a degree program (e.g., bachelor's, master's), rather than the learning goals for individual majors or concentrations within a degree program (Marshall, 2007). For example, a school with a Bachelor of Science degree program (BS) may have several majors (e.g., Accounting, Finance, Management Marketing, etc.). All of these major programs should have the same degree program learning goals. 


\section{Implementation of AOL at the Degree Program Level}

This section discusses an AOL process implemented at the business school of a middle-sized public university in New Jersey, USA, in compliance with the 2013 AACSB AOL Standards. The business school has 8 undergraduate major programs. It received the AACSB accreditation under the 2003 Standards and is currently in the process of applying for re-accreditation under the 2013 Standards.

To comply with the new accreditation standards, the school revised its AOL process. Since the AACSB AOL-related accreditation standards are stated at the degree program level, the school's AOL framework was developed at the college level with the program learning goals mapped into the business core courses. The assessment plan was then developed and implemented at the business core course level. The assessment results were used to close the loop, i.e., developing an action plan for the ongoing business program and its curriculum management and improvement and for enhancing student learning experiences.

Development of the AOL framework at the degree program level includes: (1) state clearly the program learning goals; these goals usually have conceptual definitions; (2) define learning objectives for each program learning goal; these learning objectives should have operational definitions; and (3) map the program learning objectives into business core courses with the specifications as where each program learning objective is introduced and reinforced and where and how often the AOL assessment data will be collected. This stage leads to a rubric that ties the degree program goals to most, if not all, business core courses and shows the overall assessment plan at the degree program level. A college-wide AOL committee is needed with one faculty representative from each business core course.

Development of the assessment plan at business core course level includes: (1) develop course-based measurable assessment criteria for each business core course, based on its assigned degree program learning objective(s); (2) select assessment instrument(s) for coursebased assessment criteria; and (3) define performance levels (used to group students; e.g. excellent, satisfactory, and unsatisfactory) and target performance (e.g., at least $90 \%$ of students will perform at satisfactory or higher level). The assessment instruments may be direct or indirect, course-embedded, case studies, team projects/papers, presentations, etc. The literature has provided rich sources about this subject (Bamford et al., 2012; Gibson, 2011; Jayashree \& Mitra, 2012; McConnell et al., 2008; Payne et al., 2008; Phelps \& Spangler, 2013; Price \& Randall, 2008; Weldy \& Turnipseed, 2010). In summary, this stage leads to a coursebased assessment rubric for each business core course involved. This rubric details the assessment activities and can be used for assessment data collection and reporting. This stage requires collaborative teamwork among the faculty members who teach the same course. A course coordinator is needed to play an instrumental role.

The last stage of AOL at the degree program level is to implement the program assessment plan at the business core course level and utilize the assessment results to close the loop. It requires that all faculty members who teach the same business core course follow the established assessment plan, use the same assessment tool, and collect the assessment data during the same planned semester. A course coordinator is needed to send out assessment reminders and aggregate the data from all sections. The gaps between expected performance and actual performance are identified and an action plan is developed accordingly to close the 
loop, i.e., to reduce or eliminate any discrepancies. The assessment results may further be utilized for ongoing curricula management and improvement.

\section{Background}

\section{AOL AT THE MAOR LEVEL FOR MSCHE ACCREDITATION}

The Council for Higher Education Accreditation (CHEA) is the largest nongovernmental higher education organization in the Unites States. It promotes academic quality through accreditation. Currently, CHEA is an association of 3,000 degree-granting colleges and universities, and has 6 regional accrediting agencies (CHEA, 2017).

The Middle States Commission on Higher Education (MSCHE) is one of the six regional accrediting agencies under CHEA. It mainly accredits colleges and universities in the Middle States region of the United States. In recent years, higher education institutions in some other countries have also started to adopt MSCHE accreditation as a form of external quality assurance (Cheng, 2015; Ramirez, 2015). To achieve and maintain MSCHE accreditation, an institution must demonstrate that it fully meets the 15 requirements of affiliation and 7 standards for accreditation and that it engages in an ongoing process of self-review and improvement (MSCHE, 2017a).

The MSCHE Standard V addresses educational effectiveness assessment and focuses on AOL: "Assessment of student learning and achievement demonstrates that the institution's students have accomplished educational goals consistent with their program of study, degree level, the institution's mission, and appropriate expectations for institutions of higher education." (MSCHE, 2017a). Notice AOL and assessment here refer to the educational expectations for a program of study, or individual majors, rather than for a degree program.

\section{Complying with MSCHE AOL Accreditation Standard at the Major Level}

This section discusses an AOL process implemented at the major level at the above referenced middle-sized public university in New Jersey, USA, in compliance with the MSCHE accreditation standards. The university has more than 80 bachelors' and 60 masters' degree programs, along with several doctoral and professional programs. Its most recent affirmed accreditation from MSCHE was in 2014 following the Periodic Review Report. Currently, the university is in the process of preparing the comprehensive ten-year Self-Study for its re-accreditation in 2019.

To comply with the MSCHE AOL and assessment standard, each academic program/major within the university is required to develop its assessment plan and document its assessment process in detail. That is, the AOL for MSCHE accreditation is mostly implemented at the department level by the faculties who teach the core courses of an academic major program (e.g., Management, Entrepreneurship, Human Resources, etc.).

The process of AOL at the major program level consists of following steps: (1) develop learning goal(s) with operational definitions for each major program goal; (2) develop specific measurable learning outcome(s) for each learning goal and map them into the curriculum for a major, i.e., showing where these learning outcomes will be introduced and assessed, and how often the assessment data will be collected; (3) develop detailed assessment plan for each major core course, including assessment tools, performance levels, and quality target; and (4) implement the assessment plan, including data collection, data analysis, and development of an action plan to reduce the gap between actual performance and target performance and close the loop. 
The learning goals for an academic major are mission-driven and state the learning expectations in general for the graduates with the major. To ensure the achievement of these program goals, one or more operational student learning goals need to be developed. Next, for the assessment purpose, some more specific and measurable learning outcomes need to be defined for each learning goal. All these need to be mapped into the major's core curriculum to show the how program goals, learning goals, and learning outcomes are mapped into the major core curriculum and where and how often the assessment will be implemented. An example of this program goal and major core curriculum mapping is shown in Table 2. Again, the AOL process is carried out at the academic major level (most likely within a department) and requires the participation of the all faculty members who teach the core courses for a major.

Table 2: Mapping Program Goals into Major Curricula for AOL and Assessment

\begin{tabular}{|c|c|c|c|}
\hline $\begin{array}{c}\text { Major Program } \\
\text { Goal }\end{array}$ & Learning Goals & Learning Outcomes & $\begin{array}{l}\text { Where to Assess } \\
\text { and How Often }\end{array}$ \\
\hline \multirow{4}{*}{$\begin{array}{l}\text { Graduates will } \\
\text { be able to solve } \\
\text { qualitative \& } \\
\text { quantitative } \\
\text { management } \\
\text { problems. }\end{array}$} & \multirow{2}{*}{$\begin{array}{l}\text { 1. Student will be } \\
\text { able to use } \\
\text { quantitative tools for } \\
\text { problem solving. }\end{array}$} & $\begin{array}{l}\text { 1.1. Students will be able to perform } \\
\text { basic data analysis for managerial } \\
\text { decision making }\end{array}$ & $\begin{array}{l}\text { Decision Making } \\
\text { Tools for Managers } \\
\text { (Annual) }\end{array}$ \\
\hline & & $\begin{array}{l}\text { 1.2. Students will be able to apply } \\
\text { essential qualitative models to } \\
\text { solve business problems. }\end{array}$ & $\begin{array}{l}\text { Decision Making } \\
\text { Tools for Managers } \\
\text { (Annual) }\end{array}$ \\
\hline & \multirow[b]{2}{*}{$2 . \ldots$} & $2.1 \ldots$ & \\
\hline & & & \\
\hline
\end{tabular}

Following the AOL and assessment framework shown in Table 2, a detailed assessment implementation plan for each course is then developed; including assessment tools, performance levels, and quality targets. Assessment tools maybe direct or indirect. Some common choices include: course-embedded assessment (tests, case studies, presentations, etc.), employer evaluations, and surveys (graduating senior survey, employee survey, alumni survey, etc.). Performance levels will be used to group students (e.g., excellent, good, fair, poor, etc.) and with a quality target as the minimal learning expectation (e.g., at least $80 \%$ of students will perform at good or excellent levels). A course coordinator for each course is needed to play an instrumental role, if more than one faculty member teaches the same course.

The last step of the AOL process at the major level is to implement the assessment plan. It includes collecting and analyzing assessment data, identifying learning weaknesses and any gap(s), and developing an improvement action plan to close the loop. The assessment results may lead to revisiting the major's program goals and learning goals. The improvement plan may be related to ongoing curriculum management and improvement, and actions for reducing or eliminating any discrepancies between quality targets and actual student performance.

\section{DISCUSSION}

The accreditation by AACSB is sought by business schools and the AOL and assessment for this accreditation are carried out at the degree program level, rather than at the academic major level. The focuses are degree program goals, the associated learning objectives, and their mapping to the business core courses. The implementation of AOL at this level requires institutional support and the commitment of the business school. A college-wide committee with a faculty coordinator from each business core course is needed. 
The accreditation by MSCHE is sought by colleges and universities and the AOL and assessment for this accreditation are carried out at the academic major level. The focuses are major program goals, the associated learning objectives, and their mapping to the majors' curriculum. The implementation of AOL at this level requires institutional support, departmental commitment, and teamwork among the faculty members who teach the core courses for the same major program.

Some comments from the implementation of AOL and assessment at the degree program level and the major levels:

1. A faculty member may be involved in both levels of assessment, if he/she teaches both a business core course and a major core course. When that is the case, it is important to recognize the similarities and differences in AOL between these two levels.

2. The key for a successful AOL process, both at the degree program level and at the major level, is to utilize the assessment results to close the loop - for ongoing program and curriculum management and improvement, and for continuous learning enhancement.

3. Several operational learning goals maybe used to represent a conceptual/general program goal for the assessment purpose. However, they do not need to be assessed at once. For example, if there were four learning goals for a program goal, an initial AOL and assessment plan may only focus on two of them.

4. The assessment plan may be carried out annually, rather than every semester. This may be appropriate as it takes time to implement an action plan and to see the results.

\section{References}

AACSB (2013). Eligibility procedures and accreditation standards for business accreditation. www.aacsb.edu/accreditation/standards. Accessed on Feb. 20, 2017.

AACSB (2017). www.aacsb.edu/accreditation/accreditated-members. Accessed on March 1, 2017.

Abdelsamad, M., Farmer, B., McNeil, R., \& Stevens, G. (2015). Major changes in AACSB standards (2003, compared to 2013). Advanced Management Journal, 80(3), 4-11.

Bamford, D., Karjalainen, K., \& Jenavs, E. (2012). An evaluation of problem-based assessment in teaching operations management. International Journal of Operations \& Production Management, 32(12), 1493-1514.

CHEA (2017). CHEA At-A-Glance. www.chea.org. Accessed on Feb. 20, 2017.

Cheng, N. (2015). A comparison of compliance and aspirational accreditation models: Recounting a university's experience with both a Taiwanese and an American accreditation body. High Educ, 70, 1017-1032.

Gibson, J. (2011). Measuring course competencies in a school of business: The use of standardized curriculum and rubrics. American Journal of Business Education, 4(8), 1-6.

Jayashree, P. \& Mitra, S. (2012). Facilitating a deep approach to learning: An innovative case assessment technique. Journal of Management \& Organization, 18(4), 555-572.

Marshall, L. (2007). Measuring assurance of learning at the degree program and academic major levels. Journal of Education for Business, November/December, 101-109.

McConnell, C., Hoover, G., \& Miller, G. (2008). Course embedded assessment and assurance of learning: Examples in business disciplines. Academy of Educational Leadership Journal, 12(3), 19-34.

Michlitsch, J. \& Sidle, M. (2002). Assessing student learning outcomes: A comparative study of techniques used in business disciplines. Journal of Education for Business, 77(3), 125-130.

Miles, M., Franklin, G., Grimmer, M., \& Heriot, K. (2015). An exploratory study of the perception of AACSB international's 2013 accreditation standards. Journal of International Education in Business, 8(1), 2-17.

Miles, M., Franklin, G., Heriot, K., Hadley, L., \& Hazeldine, M. (2014). AACSB international's 2013 accreditation standards -Speculative implications for faculty and deans. Journal of International Education in Business, 7(2), 86107.

MSCHE (2017a). Standards for Accreditation and Requirements of Affiliation (13 ${ }^{\text {th }}$ Ed). http://www.msche.org. Accessed on Feb. 20, 2017. 
MSCHE (2017b). www.msche.org/institutions directory.asp. Accessed on March 1, 2017.

Payne, S., Flynn, J., \& Whitfield, J. (2008). Capstone business course assessment: Exploring student readiness perspectives. Journal of Education for Business, January/February, 141-146.

Phelps, A. \& Spangler, W. (2013). Customized versus standardized exams for learning outcomes assessment in an undergraduate business program. American Journal of Business Education, 6(5), 521-530.

Price, B. \& Randall, C. (2008). Assessing learning outcomes in quantitative courses: Using embedded questions for direct assessment. Journal of Education for Business, May/June, 288-294.

Ramirez, G. (2015). International accreditation as global position taking: An empirical exploration of U.S. accreditation in Mexico. High Educ, 69, 361-374.

Weldy, T. \& Turnipseed, D. (2010). Assessing and improving learning in business schools: Direct and indirect measures of learning. Journal of Education for Business, 85, 268-273. 